\title{
INVESTMENT DETERMINANTS OF FITNESS SMES IN PORTUGAL
}

\author{
Paulo Maçãs NUNES ${ }^{\mathrm{a}}$, Zélia SERRASQUEIRO ${ }^{\mathrm{b}}$, Pedro GUEDES DE CARVALHO ${ }^{c}$ \\ ${ }^{\mathrm{a}, \mathrm{b}}$ Management and Economics Department, Beira Interior University \\ and CEFAGE Research Center, Évora University, Portugal \\ 'Sport Sciences Department, Beira Interior University and CIDESD Research Center, \\ UTAD University, Portugal
}

Received 23 October 2012; accepted 02 November 2013

\begin{abstract}
Based on a sample of 182 Portuguese fitness SMEs we study the investment determinants of fitness SMEs in Portugal. The multiple empirical evidence obtained in this study lets us conclude that the main explanatory theories of firm investment cannot be considered mutually exclusive in explaining the investment of Portuguese fitness SMEs, since: 1) they adjust investment as a function of sales, corroborating the assumptions of Neoclassical theory; 2) cash flow is an important financial resource for investment, corroborating the assumptions of Free Cash Flow theory; and 3) external finance, namely debt, is a restrictive determinant of investment, which corroborates the assumptions of Agency theory. Besides these results, we find that growth opportunities and government subsidies are positive determinants of investment in Portuguese fitness SMEs, and the financial crisis of 2008 has a negative influence on investment in Portuguese fitness SMEs. The financial crisis of 2008 also means greater relative importance of cash flow and government subsidies for increased investment, and debt for diminished investment, in fitness SMEs.
\end{abstract}

Keywords: agency theory, fitness SMEs, free cash flow theory, investment, neoclassical theory, strategic property management.

Reference to this paper should be made as follows: Nunes, P. M.; Serrasqueiro, Z.; Guedes de Carvalho, P. 2013. Investment determinants of fitness SMEs in Portugal, Technological and Economic Development of Economy 19(Supplement 1): S496-S523.

JEL Classification: C23, G31, G32, L26.

Corresponding author Paulo Maçãs Nunes

E-mail: macas@ubi.pt 


\section{Introduction}

Various theories have attempted to explain firms' investment decisions. In this domain, Neoclassical, Free Cash Flow and Agency theories stand out. According to Neoclassical theory (Hall, Jorgenson 1967; Jorgenson 1971; Chirinko 1993), sales are the main explanatory factor of firm investment. If there is a positive evolution of sales, firms increase investment, that investment diminishing if sales fall. In the context of Neoclassical theory, financial structure is of negligible importance in explaining firm investment. Fazzari et al. (1988), Fazzari and Petersen (1993) were the precursors of Free Cash Flow theory. According to Free Cash Flow theory, internal finance, and more specifically cash flow, is especially relevant in explaining firm investment, with that importance increasing as firms' access to credit is restricted, as a consequence of the information asymmetry implicit in relationships formed between owners/ managers and creditors. Finally, according to Agency theory, the problems of information asymmetry implicit in relationships between owners/managers and creditors can also affect firm investment (Jensen, Meckling 1976). According to Jensen and Meckling (1976), owners/ managers can be attracted to investing in high-risk projects which increase the likelihood of firm bankruptcy. Recognizing this behaviour, creditors transfer the consequences of high-risk investments to owners/managers, increasing the cost of credit. Considering the problems of information asymmetry between owners/managers and creditors, according to Agency theory, a negative relationship can be expected between debt and firm investment.

Small and medium-sized enterprises (SMEs) have particular characteristics (Diamond 1989; Ang 1991): 1) smaller size; 2) greater likelihood of bankruptcy; 3) greater capacity to change the nature of their assets; and 4) less transparence in the information provided to creditors about firms' specific characteristics. When internal finance is insufficient, these SME characteristics can mean particular difficulty in accessing external finance, affecting their investment options.

Small service firms have particular characteristics that can mean different market and financing strategies (Roofthooft 2010; Cho et al. 2011, 2012; Serrasqueiro et al. 2011). In this context, fitness firms are service firms that are generally small in size, and may therefore have particular market and financing strategies.

At present, fitness firms provide important services to the population. Physical activity is seen today as preventive medicine (Andersen-Hanley et al. 2010; Garber et al. 2011). Indeed, it is known that the European social and economic context currently presents great financial restrictions in public health systems and retirement pensions. The consequence of those restrictions will have to mean daily routines that include physical exercise accompanied by specialist professionals. In this context, fitness firms are appropriate places for this purpose (Dale et al. 2009; Garber et al. 2011).

The study of firms' investment determinants has neglected analysis of small and young service firms. This study aims firstly to fill that gap in the literature, analysing the investment determinants of Portuguese fitness SMEs. The choice of Portuguese fitness SMEs as the subject of analysis in this paper is appropriate for two fundamental reasons: 1) fitness SMEs in Portugal are quite small and young service firms, filling the gap in the literature concerning study 
of the determinants of small, young service SMEs; and 2) fitness SMEs are quite important service firms at present, with study of their investment determinants being needed in order to suggest economic policy measures to support this type of important service.

Methodologically, we use a sample of 182 fitness SMEs in Portugal for the period 2004-2009. To estimate results, we use fixed effects models estimating standard deviations according to the cluster option. This option allows us to obtain results according to any pattern of heteroskedasticity and autocorrelation.

The results obtained allow us to make an important contribution to the literature on service SME investment. The results of the paper indicate that even in small, young service firms, the main explanatory theories of investment are not mutually exclusive in explaining investment decisions, since sales and cash flow are positively related to investment and debt is negatively related to investment. It is particularly important to find that Neoclassical theory is relevant in explaining the investment decisions of fitness SMEs, which indicates that firms' small size and young age does not always contribute to them not adjusting investment as a function of sales. In addition, growth opportunities and government subsidies have a positive influence on investment in Portuguese fitness SMEs and the financial crisis of 2008 has a negative influence on their investment. Additionally, the financial crisis of 2008 contributes to greater relevance of cash flow and government subsidies for increased investment in Portuguese fitness SMEs and greater relevance of debt for reduced investment.

After this introduction, the paper is structured as follows: 1 ) section 1 presents the literature review and research hypotheses; 2 ) section 2 presents the methodology, namely the database, variables used and estimation method; 3 ) section 3 presents the results; 4) section 4 goes on to discuss the results; and 5) the final section presents the conclusion and implications of the paper.

\section{Literature review and research hypotheses}

\subsection{Sales}

According to Neoclassical theory (Hall, Jorgenson 1967; Jorgenson 1971; Chirinko 1993), the coefficient of the sales variable is predominant, and statistically significant, in explaining firms' investment decisions. The authors corroborate the arguments of Modigliani and Miller (1958) that firms' investment decisions are not dependent on their financial structure, since firms increase investment if sales increase and reduce it if sales are falling.

Eisner (1963) and Chirinko (1993) conclude that sales are statistically predominant over any other variables of investment in explaining firms' investment decisions. However, the conclusions of Eisner (1963) and Chirinko (1993) refer to the analysis of large firms which are subject to fewer credit restrictions than small firms. In SMEs, the importance of sales is expected to be less than what may be the case in large firms. In smaller firms, sales are more volatile, which leads these firms to maintain a suitable level of assets with a greater degree of liquidity, to avoid debt on unfavourable terms (Devereux, Schiantarelli 1990). Consequently, sales can be assumed to be more important for SMEs to cope with treasury difficulties rather than a way to finance investment. 
It is also of note that, according to the Neoclassical theory of investment, sales emerge as the variable with most explanatory power in large firm investment, as proposed by the concept of the representative firm. In this context, and considering that fitness SMEs are generally small scale, we can expect sales not to be particularly important in the investment-decision process of this type of firm. Based on the above arguments, we formulate the following research hypothesis:

H1: Sales are not a positive determinant of investment in fitness SMEs.

\subsection{Cash flow}

Stiglitz and Weiss (1981) state that firms with different financial situations obtain different financing conditions in credit markets. In this connection, Fazzari et al. (1988) conclude on the need to break with the concept of the representative firm, proposing in its place another concept named financial hierarchy. According to Fazzari et al. (1988), this concept is extremely relevant in the context of information asymmetry, which occurs in the credit and capital markets, unlike the "world" of Modigliani and Miller (1958) in a context of markets with perfect competition and symmetric information, and so the Neoclassical equation of investment, tested by introducing financial variables, should reveal very different sensitivity between financial variables and investment in different groups of firms. From this argument, formulation of Free Cash Flow theory is begun, based on the hypothesis of asymmetric information, where firms' internal factors, and especially cash flow, now become relevant in explaining firm investment.

Fazzari et al. (1988) show that firm investment is dependent on cash flow, finding a positive relationship between firms' level of cash flow and investment. The authors also show that the sensitivity of investment to cash flow variations is greater for firms that are more prone to credit rationing, as a consequence of the information asymmetry in relationships between shareholders/owners and creditors.

Petersen and Rajan (1995), Vermeulen (2002), Silva and Carreira (2009) argue that cash flow is a particularly relevant variable in explaining SME investment, given the lesser possibility of obtaining credit as a consequence of less capacity to provide collateral and the greater likelihood of bankruptcy.

This positive relationship between cash flow and investment tends to be stronger in SMEs (Lee, Ratti 2008), as they are the ones most likely to suffer financial restrictions since their lack of experience and reputation in the external financing market forces them to fund themselves firstly through recourse to cash flow (Evans, Jovanovic 1989; Gilchrist, Himmelberg 1995; Xu 1998; Beck et al. 2006; Brown et al. 2009).

In general, fitness SMEs are small in size and so we can expect them to have particular difficulties in accessing external finance to fund their investment, with internal finance being especially important for this purpose. Based on these arguments, we formulate the following research hypothesis:

$\mathrm{H} 2$ : Cash flow is a positive determinant of investment in fitness SMEs. 


\subsection{Debt}

Agency theory (Jensen, Meckling 1976; Jensen 1986; Stulz 1990) is based on two types of conflicts: 1) conflicts between owners and managers; and 2) conflicts between owners/managers and creditors. While the first type of conflict is more likely to occur in large firms, the second is more applicable in small firms, where there is greater probability of bankruptcy and ownership and management usually coincide.

Indeed, in the SME context, problems of information asymmetry associated with relationships between owners/managers and creditors are particularly relevant, since in the great majority of cases SME ownership and management is in the same hands, with problems of information asymmetry in relationships between owners and managers being of marginal importance.

Jensen and Meckling (1976) claim that when a firm uses outside capital, conflicts of interest arise between shareholders/owners and creditors. Increasing the level of debt, whether to lower the agency costs of equity or for any other reason, can lead the firm to face another type of cost: the agency cost associated with outside capital. This cost, created by the conflict of interest between shareholders/owners and creditors, forms a major limitation in firms' recourse to debt. Creditors restrict the amount of credit granted to firms or increase its cost (Jensen, Meckling 1976; Stiglitz, Weiss 1981), since shareholders/owners can invest in highrisk projects, aiming to increase equity value rather than the value of the debt. Therefore, if the project succeeds, owners receive most of the gains, whereas if the project fails, creditors bear most of the costs (Jensen, Meckling 1976). Based on agency problems, Myers (1977) and Zwiebel (1996) conclude that a negative relationship is expected between debt and the level of firm investment, since creditors hinder access to credit in situations of greater information asymmetry concerning the profitability and risk of projects, with finance only being channelled to more profitable and low-risk projects.

Considering that fitness firms are generally small in size, we can expect these firms to have particular difficulty in accessing debt, and paying off the debt and its charges will mean diminished investment. Based on these arguments, we formulate the following research hypothesis:

H3: Debt is a restrictive determinant of investment in fitness SMEs.

\subsection{Other determinants of investment}

\subsubsection{Age}

Gilchrist, Himmelberg (1995) and Moyen (2004) argue that younger, smaller firms tend to invest more based on their cash flow. Beck et al. (2006) argue that the younger age of a firm is a proxy for the financial restrictions it suffers in financing its investment. The authors also state that as firms get over the first years of their life, the restrictions felt in financing their investment become less.

Fazzari et al. (1988), and Gilchrist and Himmelberg (1995) argue that although younger, smaller firms invest more, their investment is greatly subject to their liquidity restrictions. 
Fagiolo and Luzzi (2006) corroborate these arguments, concluding that liquidity restrictions create a negative effect on firm growth, with the smallest firms growing more after controlling liquidity restrictions.

Devereux, Schiantarelli (1990) and Oliner, Rudebusch (1992) concluded that young firms register greater sensitivity of investment to cash flow, suggesting the youngest firms face more obstacles in obtaining finance. In this context, Diamond (1989) states that age can serve as a proxy for firm reputation, and so we can expect that as firm age increases, there will be a greater possibility of obtaining finance on more advantageous terms.

Considering that fitness firms are generally small and consequently exposed to greater problems in financing their investment, age may contribute to increasing firm reputation, allowing them to obtain finance on more advantageous terms, which may mean increased investment. Based on the arguments presented, we formulate the following hypothesis:

H41: Age is a positive determinant of investment in fitness SMEs.

\subsubsection{Growth opportunities}

Authors such as Fazzari et al. (1988), Ascioglu et al. (2008), Carpenter and Guariglia (2008), Junlu et al. (2009), Sun and Nobuyoshi (2009) find a positive relationship between growth opportunities and investment. According to Carpenter and Guariglia (2008), the explanatory power of this variable seems to be greater in SMEs, as these are firms suffering most from financial restrictions resulting from assessment by external creditors. Fagiolo and Luzzi (2006) conclude that younger, smaller firms should benefit from greater growth opportunities and need higher levels of investment to satisfy the multiple growth opportunities that arise.

Considering that fitness firms are generally small, and consequently with greater growth opportunities, and considering that creditors can recognize the good growth opportunities in this type of firm, we can expect growth opportunities to contribute to increased levels of investment. Based on the arguments presented, we formulate the following hypothesis:

H42: Growth opportunities are a positive determinant of investment in fitness SMEs.

\subsubsection{Government subsidies}

According to Smallbone et al. (2010), government financial support is fundamental for the growth, and survival, of small firms, so that this type of firm can cope with possible restrictions in accessing finance. Peng (2003) and Manolova et al. (2008) state that the activities of small firms are particularly influenced by external factors, for example, macroeconomic conditions. Baker et al. (2005) and Smallbone, Welter (2006) conclude that public financing policies should consider the special difficulties of small firms, directing specific financial support to those with good investment projects but with clearly insufficient internal funds to finance them. Serrasqueiro et al. (2011) conclude that service SMEs are particularly affected by problems of information asymmetry in the relationships formed with creditors, which can be problematic in terms of financing their activities when internal finance is found to be insufficient. Serrasqueiro et al. (2011) suggest that when this is the case, service SMEs should receive specific financial support through public finance. 
Considering that fitness firms are generally small and consequently with particular difficulty in accessing external finance, we can expect that when internal finance is insufficient, government subsidies will be especially important for investment. Based on the arguments presented, we formulate the following research hypothesis:

H43: Government subsidies are a positive determinant of investment in fitness SMEs.

\subsubsection{Financial crisis}

According to Vermoesen et al. (2013), the global financial crisis implies greater difficulties for SMEs in accessing external finance. According to the authors, the particular characteristics of SMEs, such as: 1) greater likelihood of bankruptcy; 2) lower quality of information supplied to creditors; and 3) greater ease in changing the composition of their assets, compared to the case of large firms, may contribute decisively to SMEs having particular difficulties in accessing external finance in the context of a global financial crisis, thereby reducing their levels of investment.

SMEs can be expected to experience particular difficulties in accessing external finance in periods of financial crisis, since creditors make terms of credit especially difficult at such times. Therefore, SME investment at times of financial crisis will be particularly dependent on internal funding and possible government subsidies, debt being of a particularly restrictive nature. Based on the above, we formulate the following research hypotheses:

H44: At times of financial crisis, the investment of fitness SMEs is less.

H45: At times of financial crisis, internal finance and government subsidies are particularly relevant for fitness SME investment.

H46: At times of financial crisis, debt is a more restrictive determinant of fitness SME investment.

\section{Methodology}

\subsection{Database}

This study uses the SABI (Analysis System of Iberian Balance Sheets) database from Bureau van Dijks for the period 2004-2009. As our subject of analysis is fitness SMEs, we use the NACE classification to select firms belonging to sub-sector 93.13. Fitness, and as we are analysing SMEs, for the final selection of firms we follow the European Union recommendation L124/36, (2003/361/CE). Accordingly, a firm is considered an SME when it satisfies two of the following three criteria: 1) fewer than 250 employees; 2) annual total assets under 43 million euros; and 3) business turnover under 50 million euros.

So as to avoid bias of the results obtained, and simultaneously have a more representative sample of the fitness SME situation in Portugal, we consider: 1) fitness SMEs belonging to the market for the whole period of analysis (2004-2009); 2) fitness SMEs that enter the market during the period of analysis (2004-2009); and 3) fitness SMEs that leave the market during the period of analysis (2004-2009). 
The final sample is made up as follows: 1) 67 fitness SMEs present in the market for the whole period of analysis (2004-2009); 2) 79 fitness SMEs that enter the market during the period of analysis (2004-2009); and 3) 36 fitness SMEs that leave the market during the period of analysis (2004-2009).

The following Table 1 presents the structure of the sample used in this study.

Table 1. Sample description

\begin{tabular}{lcc}
\hline \multicolumn{3}{c}{ Fitness SMEs } \\
\hline & Firms & Observations \\
\hline Incumbent firms in all period 2004-2009 & 67 & 335 \\
\hline Firms entering in the period 2004-2009 & 79 & 256 \\
\hline Firms exiting in the period 2004-2009 & 36 & 133 \\
\hline Total of Firms & 182 & 724 \\
\hline
\end{tabular}

Aiming to compare the empirical evidence of the determinants of investment in fitness SMEs with other types of SMEs, we turn to the European Union recommendation L124/36, (2003/361/CE) to select a sample of manufacturing SMEs for the period 2004-20091. 478 manufacturing SMEs were selected: 1) 235 manufacturing SMEs present in the market for the whole period of analysis (2004-2009);2) 123 manufacturing SMEs that enter the market during the period of analysis (2004-2009); and 3) 120 manufacturing SMEs that leave the market during the period of analysis (2004-2009).

\subsection{Variables}

The dependent variable is the investment of fitness SMEs, given by the ratio of fixed capital variation in the present period to fixed assets in the previous period ${ }^{2}$. As principal independent variables, we consider: 1) sales; 2) cash flow; and 3) debt. As control variables, we also consider the following investment determinants of fitness SMEs: 1) age; 2) growth opportunities; 3) government subsidies; and 4) a dummy variable representing the financial crisis.

The following Table 2 presents the variables used in this study, their corresponding measures, and the expected influence of explanatory variables on dependent variable. Monetary variables are deflated according to inflation in Portugal. We construct a price index from 2004 to 2009 . 2009 is taken as the base year.

\subsection{Estimation method}

To estimate results, we use various types of regressions. Initially, we estimate regressions considering determinants representing the main explanatory theories of investment, namely sales as a variable representing Neoclassical theory, cash flow as a variable representing Free Cash Flow theory, and debt as a variable representing Agency theory. Afterwards, we consider

1 We use NACE classification to select manufacturing SMEs: codes 10 to 33 .

2 Aiming to test the robustness of the results obtained, we use an alternative measure of investment, namely net investment, given by the ratio of fixed assets variation (i.e. fixed assets in the present period less fixed assets in the previous period) less depreciations to fixed assets in the previous period. 
Table 2. Variables and measurement

\begin{tabular}{|c|c|c|}
\hline Variables & Measurement & $\begin{array}{c}\text { Expected Influence } \\
\text { of Explanatory Variables } \\
\text { on Dependent Variable }\end{array}$ \\
\hline Investment $\left(\mathrm{I}_{\mathrm{i}, \mathrm{t}}\right)$ & $\begin{array}{l}\text { Ratio of fixed assets variation } \\
\text { (i.e. fixed assets in present period less fixed } \\
\text { assets in previous period) to fixed assets } \\
\text { in the previous period }\end{array}$ & \\
\hline Sales $\left(\right.$ SALES $\left._{\mathrm{i}, \mathrm{t}}\right)$ & Logarithm of sales & Not significant \\
\hline Cash Flow $\left(\mathrm{CF}_{\mathrm{i}, \mathrm{t}}\right)$ & Ratio of earnings after taxes to total assets & + \\
\hline Debt $\left(\mathrm{LEV}_{\mathrm{i}, \mathrm{t}}\right)$ & Ratio of total liabilities to total assets & - \\
\hline Age $\left(\mathrm{AGE}_{\mathrm{i}, \mathrm{t}}\right)$ & $\begin{array}{l}\text { Logarithm of the number of years since } \\
\text { starting activity }\end{array}$ & - \\
\hline $\begin{array}{l}\text { Growth Opportunities } \\
\left(\mathrm{GO}_{\mathrm{i}, \mathrm{t}}\right)\end{array}$ & Ratio of intangible assets to total assets & + \\
\hline $\begin{array}{l}\text { Government Subisdies } \\
\left(\mathrm{GS}_{\mathrm{i}, \mathrm{t}}\right)\end{array}$ & $\begin{array}{l}\text { Ratio between government subsidies } \\
\text { and total assets }\end{array}$ & + \\
\hline $\begin{array}{l}\text { Dummy Financial Crisis } \\
\left(\mathrm{D}_{08-09}\right)\end{array}$ & $\begin{array}{l}\text { Dummy with value } 1 \text { in } 2008 \text { and } \\
2009 \text { years and } 0 \text { in other years }\end{array}$ & - \\
\hline
\end{tabular}

in the regressions other possible determinants of investment, namely age, growth opportunities and government subsidies. In addition, we consider a dummy variable representing the financial crisis of 2008. Finally, we consider in the regressions interaction variables between the dummy representing the financial crisis of 2008 and the financial variables considered in the paper, namely cash flow, debt and government subsidies, aiming to determine the influence of the financial crisis of 2008 on the impact of financial variables on investment.

The regressions to estimate can be presented as follows:

$$
I_{i, t}=\beta_{0}+\beta_{K} X_{k, i, t-1}+u_{i}+e_{i, t}
$$

where: $X_{k, i, t-1}^{\star}$ is the vector of independent variables:

$$
\begin{gathered}
X_{1, i, t-1}^{*}=f\left(S A L E S_{i, t-1}, C F_{i, t-1}, L E V_{i, t-1}, d_{t}\right) ; \\
X_{2, i, t-1}^{\star}=f\left(S A L E S_{i, t-1}, C F_{i, t-1}, L E V_{i, t-1}, A G E_{i, t-1}, G O_{i, t-1}, G S_{i, t-1}, d_{t}\right) ; \\
X_{3, i, t-1}^{\star}=f\left(S A L E S_{i, t-1}, C F_{i, t-1}, L E V_{i, t-1}, A G E_{i, t-1}, G O_{i, t-1}, G S_{i, t-1}, D_{08-09}\right),
\end{gathered}
$$

where: SALES $_{\mathrm{i}, \mathrm{t}-1}$ are sales in the previous period; $\mathrm{CF}_{\mathrm{i}, \mathrm{t}-1}$ is cash flow in the previous period; $\mathrm{LEV}_{\mathrm{i}, \mathrm{t}-1}$ is debt in the previous period; $\mathrm{AGE}_{\mathrm{i}, \mathrm{t}-1}$ is age in the previous period; $\mathrm{GO}_{\mathrm{i}, \mathrm{t}-1}$ are growth opportunities in the previous period; $\mathrm{GS}_{\mathrm{i}, \mathrm{t}-1}$ are government subsidies in the previous period; $\mathrm{D}_{08-09}$ is the dummy variable representing the financial crisis of 2008; $\mathrm{d}_{\mathrm{t}}$ are annual dummy variables; $u_{i}$ are not directly observable fixed effects; and $e_{i, t}$ is the error term which is assumed to have normal distribution.

At a later stage, aiming to test the effect of the 2008 financial crisis on the relationship between the financial variables (CF, LEV, GS) and investment in fitness SMEs, we estimate the relationships between determinants and fitness SME investment in the periods 2008-2009 and 
in the period 2004-2007. Initially, we only consider the impact of the determinants: CF, LEV and GS on investment in fitness SMEs. Subsequently, we also consider the other principal remaining investment determinants considered in the study, namely: SALES, AGE and GO. The regressions to estimate can be presented as follows:

$$
I_{i, t}=\beta_{0}+\beta_{K} X_{k, i, t-1}+u_{i}+e_{i, t},
$$

where: $X_{k, i, t-1}^{\star}$ is the vector of independent variables:

$$
\begin{gathered}
X_{4, t-1}^{\star}=f\left(C F_{i, t-1}, L E V_{i, t-1} G S_{i, t-1}, d_{t}\right) ; \\
X_{5, i, t-1}^{\star}=f\left(C F_{i, t-1}, L E V_{i, t-1}, G S_{i, t-1}, S A L E S_{i, t-1}, A G E_{i, t-1}, G O_{i, t-1}, d_{t}\right) .
\end{gathered}
$$

Mateev and Anastasov (2011), Antão and Bonfim (2012) control for the effects of firm size and age on the results obtained, respectively, between determinants and firm growth and between determinants and firm debt. The fact that the great majority of fitness SMEs are small and young prevents us from making a division between micro fitness, small fitness and medium-sized fitness, and between young fitness and old fitness, since sub-samples of small fitness and medium-sized fitness, and of old fitness would contain a very limited number of firms. Therefore, aiming to test the effect of size and age on relationships between the determinants: SALES, CF, LEV, AGE, GO, GS, and investment, initially we consider two dummy variables: 1 ) a dummy variable with the value of 1 if the size of fitness SMEs at a given moment is above the median of size and 0 if it is under the median; and 2) a dummy variable with the value of 1 if the age of fitness SMEs at a given moment is above the median of age and 0 if it is under the median. Then we multiply the dummy variables by the determinants: SALES, CF, LEV, AGE, GO, GS. In these circumstances the regressions to estimate can be presented as follows:

$$
I_{i, t}=\beta_{0}+\beta_{K} X_{k, i, t-1}+u_{i}+e_{i, t},
$$

where: $X_{k, i, t-1}^{\star}$ is the vector of independent variables:

$$
\begin{aligned}
& X_{6 i, t-1}^{*}=f\left(D_{S} \times S A L E S_{i, t-1}, D_{S} \times C F_{i, t-1}, D_{S} \times L E V_{i, t-1}, d_{t}\right) ; \\
& X^{*}{ }_{7 i, t-1}=f\left(D_{S} \times S A L E S_{i, t-1}, D_{S} \times C F_{i, t-1}, D_{S} \times L E V_{i, t-1}, D_{S} \times\right. \\
& \left.A G E_{i, t-1}, D_{S} \times G O_{i, t-1}, D_{S} \times G S_{i, t-1}, d_{t}\right) ; \\
& X_{8, i, t-1}^{\star}=f\left(D_{A} \times S A L E S_{i, t-1}, D_{A} \times C F_{i, t-1}, D_{A} \times L E V_{i, t-1}, d_{t}\right) ; \\
& X_{9 i, t-1}^{*}=f\left(D_{A} \times S A L E S_{i, t-1}, D_{A} \times C F_{i, t-1}, D_{A} \times L E V_{i, t-1}, D_{A} \times\right. \\
& \left.A G E_{i, t-1}, D_{A} \times G O_{i, t-1}, D_{A} \times G S_{i, t-1}, d_{t}\right) .
\end{aligned}
$$

Finally, we compare the results obtained for fitness SMEs with manufacturing SMEs concerning the relationships between determinants and investment. We use the Chow test to test the differences between the estimated parameters measuring the relationships between investment and determinants in fitness SMEs and manufacturing SMEs. 
In all the regressions we admit the existence of fixed effects ${ }^{3}$ considering the cluster option $^{4}$. This option allows us to estimate standard deviations consistent with any type of heteroskedasticity and autocorrelation. As we use regressions admitting the existence of fixed effects, use of lagged investment would lead to correlation between fixed effects $\left(u_{i}\right)$ and the lagged investment $\left(\mathrm{I}_{\mathrm{i}, \mathrm{t}-1}\right)$ which would mean bias of the estimated parameter measuring the relationship between investment in the previous period $\left(\mathrm{I}_{\mathrm{i}, \mathrm{t}-1}\right)$ and investment in the current period $\left(I_{i, t}\right)$. However, since we use the cluster option, the results estimated through the regressions admitting the existence of fixed effects are consistent with the possible existence of autocorrelation, and so possible autocorrelation does not mean bias in the estimated results measuring relationships between determinants and investment.

Aiming to test the robustness of the results obtained, we estimate the regressions related to the determinants of investment using an alternative measure for defining investment, namely net investment given by the ratio of variations in fixed capital less depreciation to total assets, and considering the determinants (SALES, CF, LEV, AGE, GO, GS) two periods out of step. Furthermore, we turn to OLS regressions, considering investment one period out of step as an additional determinant of investment. The results are presented in Appendix B, Table B1.

In Appendix C, so as to test the robustness of the empirical evidence obtained, we add two possible determinants of fitness SME investment not dealt with in the literature on firm investment, namely: 1) effective tax rate (ETR), measured by the ratio of total tax expenses to earnings before taxes; and 2) risk, i.e. earnings volatility (EVOL), measured by the absolute value of the ratio of variation of earnings before taxes and interest to earnings before taxes and interest in the previous period. The results are presented in Appendix C, Table $\mathrm{C}^{5}$.

\section{Results}

\subsection{Descriptive statistics and correlation matrix}

The following Table 3 presents the descriptive statistics of the variables used in this study.

From analysis of the descriptive statistics, we can see the small size and young age of fitness SMEs in Portugal. We opt to present the descriptive statistics of the size and age variables in logarithms, to agree with the definition used and the way they are introduced in

\footnotetext{
Mateev and Tsekov (2012) state the importance of considering in the regressions the non-observable individual effects of the units of analysis. In this study, by considering the existence of firms' non-observable individual effects, we consider the influence of firms' specific characteristics, not measured by the explanatory variables, on fitness SME investment, which allows us to obtain more robust explanatory models of investment in fitness SMEs.

4 According to Arellano and Bond (1991), firms must be present in the database for at least four consecutive years to be considered in the econometric analysis and in the second-order autocorrelation tests that are essential to validate the robustness of results. Since the period of analysis is not very long and some fitness SMEs are not included in the database for 4 years, for example, fitness SMEs that enter the market during the period of analysis, use of dynamic panel estimators would imply elimination of some fitness SMEs, which would lead to not considering part of the investment dynamics of fitness SMEs that enter the market during the period of analysis.

5 Firstly, we can expect a higher effective tax rate, i.e. a higher level of taxes paid in relation to taxable income, to mean diminished firm investment, since they have less capacity for investment. Secondly, we can expect firms with a higher level of operational risk to have a greater likelihood of bankruptcy, and consequently less capacity to finance their investment opportunities. We can therefore expect a higher level of risk to mean diminished investment.
} 
Table 3. Descriptive statistics

\begin{tabular}{lccccccc}
\hline Variable & Firms & Observations & Mean & Median & S.D. & Min & Max \\
\hline $\mathrm{I}_{\mathrm{i}, \mathrm{t}}$ & 182 & 724 & 0.1192 & 0.1082 & 0.2898 & -0.6718 & 4.0203 \\
\hline SALES $_{\mathrm{i}, \mathrm{t}}$ & 182 & 724 & 11.556 & 10.782 & 1.8814 & 5.0277 & 17.458 \\
\hline $\mathrm{CF}_{\mathrm{i}, \mathrm{t}}$ & 182 & 724 & 0.0716 & 0.0738 & 0.1800 & -1.5431 & 1.1475 \\
\hline $\mathrm{LEV}_{\mathrm{i}, \mathrm{t}}$ & 182 & 724 & 0.6451 & 0.5019 & 0.2144 & 0 & 0.8718 \\
\hline $\mathrm{AGE}_{\mathrm{i}, \mathrm{t}}$ & 182 & 724 & 1.8711 & 1.6094 & 0.5818 & 0 & 3.1354 \\
\hline $\mathrm{GO}_{\mathrm{i}, \mathrm{t}}$ & 182 & 724 & 0.0097 & 0 & 0.0377 & 0 & 0.3120 \\
\hline $\mathrm{GS}_{\mathrm{i}, \mathrm{t}}$ & 182 & 724 & 0.0071 & 0 & 0.0301 & 0 & 0.2589 \\
\hline $\mathrm{D}_{08-09}$ & 182 & 724 & 0.4378 & 0 & 0.4964 & 0 & 1 \\
\hline
\end{tabular}

the regressions. However, aiming for better perception of the size and age of fitness SMEs in Portugal, we present the averages of size and age without the variables being in logarithms: 1) average size is 102898.87 euros; and 2) average age is 6.2099 years. We find, therefore, that on average, besides the small size, the age of fitness SMEs is also low. In Appendix A, Table A1, we present the descriptive statistics of the variables referring to manufacturing SMEs. Compared to the size and age of manufacturing SMEs ${ }^{6}$, we find that on average the size and age of fitness SMEs are considerably lower. This fact reveals the distinct characteristics of fitness SMEs, which may have a particular effect on their investment options.

We also find that: 1) investment, cash flow, growth opportunities and government subsidies are quite volatile determinants, since the standard deviations of the variables are above the respective means; and 2) sales, debt and age are determinants showing little volatility, since the standard deviations are under the respective means.

The following Table 4 presents the correlation coefficients between the variables used in this study.

Table 4. Correlation matrix

\begin{tabular}{|c|c|c|c|c|c|c|c|c|}
\hline & $I_{i, t}$ & SALES $_{\mathrm{i}, \mathrm{t}-1}$ & $\mathrm{CF}_{\mathrm{i}, \mathrm{t}-1}$ & $\mathrm{LEV}_{\mathrm{i}, \mathrm{t}-1}$ & $\mathrm{AGE}_{\mathrm{i}, \mathrm{t}-1}$ & $\mathrm{GO}_{\mathrm{i}, \mathrm{t}-1}$ & $\mathrm{GS}_{\text {i.t-1 }}$ & $\mathrm{D}_{08-09}$ \\
\hline $\mathrm{I}_{\mathrm{i}, \mathrm{t}}$ & 1 & & & & & & & \\
\hline SALES $_{\mathrm{i}, \mathrm{t}-1}$ & $0.212^{\star *}$ & 1 & & & & & & \\
\hline $\mathrm{CF}_{\mathrm{i}, \mathrm{t}-1}$ & $0.358^{\star *}$ & $0.176^{\star *}$ & 1 & & & & & \\
\hline $\mathrm{LEV}_{\mathrm{i}, \mathrm{t}-1}$ & $-0.189^{* *}$ & 0.013 & $-0.281^{* *}$ & 1 & & & & \\
\hline $\mathrm{AGE}_{\mathrm{i},-1}$ & 0.010 & 0.017 & $0.079^{\star}$ & $0.133^{\star *}$ & 1 & & & \\
\hline $\mathrm{GO}_{\mathrm{i}, \mathrm{t}-1}$ & $0.121^{\star *}$ & -0.026 & -0.016 & -0.015 & $0.129^{\star *}$ & 1 & & \\
\hline $\mathrm{GS}_{\mathrm{i}, \mathrm{t}-1}$ & $0.242^{\star *}$ & -0.034 & $0.201^{\star *}$ & 0.017 & 0.010 & $-0.066^{*}$ & 1 & \\
\hline $\mathrm{D}_{08-09}$ & $-0.269^{\star *}$ & $-0.198^{\star *}$ & $-0.157^{\star *}$ & $-0.361^{\star *}$ & $0.219^{\star *}$ & $-0.145^{\star *}$ & $0.156^{\star *}$ & 1 \\
\hline
\end{tabular}

Notes: $1 .{ }^{*}$ Statistical significant at $1 \%$ level; ${ }^{\star}$ Statistical Significant at $5 \%$ level.

Gujarati and Porter (2010) conclude that when the correlation coefficients between independent variables are under $50 \%$, the problem of collinearity between explanatory variables

${ }_{6}$ The average size of manufacturing SMEs is 2517974.34 euros and the average age is 15.4912 years. 
will not be particularly relevant. From observation of the correlation coefficients between the independent variables used, in no circumstances are they over $50 \%$, and so the problem of collinearity between explanatory variables will not be relevant in this study ${ }^{7}$.

\subsection{Investment determinants}

The following Table 5 presents the results referring to the relationships between determinants and investment.

Table 5. Investment determinants of fitness SMEs

\begin{tabular}{|c|c|c|c|}
\hline & \multicolumn{3}{|c|}{ Dependent Variable: $I_{i, t}$} \\
\hline & I & II & III \\
\hline SALES $_{\mathrm{i}, \mathrm{t}-1}$ & $\begin{array}{l}0.02938^{\star *} \\
(0.00718)\end{array}$ & $\begin{array}{l}0.02612^{\star *} \\
(0.00672)\end{array}$ & $\begin{array}{l}0.02549^{* *} \\
(0.00583)\end{array}$ \\
\hline $\mathrm{CF}_{\mathrm{i}, \mathrm{t}-1}$ & $\begin{array}{l}1.17380^{\star *} \\
(0.20182)\end{array}$ & $\begin{array}{l}1.11094^{\star *} \\
(0.19087)\end{array}$ & $\begin{array}{l}1.07817^{* *} \\
(0.20198)\end{array}$ \\
\hline $\mathrm{LEV}_{\mathrm{i}, \mathrm{t}-1}$ & $\begin{array}{c}-0.17811^{\star *} \\
(0.06718) \\
\end{array}$ & $\begin{array}{c}-0.14859^{* *} \\
(0.03901)\end{array}$ & $\begin{array}{c}-0.16838^{\star *} \\
(0.04541) \\
\end{array}$ \\
\hline $\mathrm{AGE}_{\mathrm{i}, \mathrm{t}-1}$ & & $\begin{array}{c}0.01738 \\
(0.10839) \\
\end{array}$ & $\begin{array}{c}0.02098 \\
(0.12838) \\
\end{array}$ \\
\hline $\mathrm{GO}_{\mathrm{i}, \mathrm{t}-1}$ & & $\begin{array}{l}0.21920^{\star *} \\
(0.05681)\end{array}$ & $\begin{array}{l}0.18726^{* *} \\
(0.04858)\end{array}$ \\
\hline $\mathrm{GS}_{\mathrm{i}, \mathrm{t}-1}$ & & $\begin{array}{l}0.68190^{\star *} \\
(0.15480)\end{array}$ & $\begin{array}{l}0.70187^{* *} \\
(0.17612)\end{array}$ \\
\hline $\mathrm{D}_{08-09}$ & & & $\begin{array}{c}-0.24989^{\star *} \\
(0.06517) \\
\end{array}$ \\
\hline CONS & $\begin{array}{l}0.02012^{\star *} \\
(0.00511) \\
\end{array}$ & $\begin{array}{l}0.01617^{\star *} \\
(0.00498) \\
\end{array}$ & $\begin{array}{l}0.01710^{* *} \\
(0.00527)\end{array}$ \\
\hline $\mathrm{R}^{2}$ & 0.2238 & 0.2564 & 0.2891 \\
\hline Firms & 182 & 182 & 182 \\
\hline Observations & 542 & 542 & 542 \\
\hline
\end{tabular}

Notes: 1 . CONS is the constant of the regressions; 2 . Standard deviations in parenthesis using cluster option; 3. ${ }^{* *}$ statistical significance at $1 \%$ level, ${ }^{*}$ statistical significance at $5 \%$ level; 4 . The estimates include time dummy variables, but are not shown.

Whatever the regression estimated, the results obtained indicate that: 1) the relationship between sales and investment is positive and statistically significant; 2) the relationship between cash flow and investment is positive and statistically significant; and 3) the relationship between debt and investment is negative and statistically significant.

Regarding relationships between the other determinants and investment, we can conclude that: 1) the relationship between age and investment is not statistically significant;2) the relationship between growth opportunities and investment is positive and statistically significant;

\footnotetext{
The correlation coefficients of the variables used in the context of manufacturing SMEs are presented in Appendix A, Table A2. We also find that in no circumstances are the correlation coefficients between the independent variables above $50 \%$ and so, also when our subject of analysis is manufacturing SMEs, problems of collinearity will not be particularly relevant.
} 
3) the relationship between government subsidies and investment is positive and statistically significant; 4) the relationship between the dummy variable representing the financial crisis of 2008 and investment is negative and statistically significant.

The results presented in Appendix B, Table B1, refer to the use of an alternative measure of investment and use of the determinants (SALES, CF, LEV, AGE, GO, GS) two periods out of step. Concerning the magnitude and statistical significance of the estimated parameters, the results presented in Table B1, corroborate those presented in Table 5, confirming the empirical evidence obtained in this study.

In Appendix C, Table C1 presents the regressions of Table 5, considering two more possible determinants of fitness SME investment, namely effective tax rate (ETR) and riskearnings volatility $(\mathrm{EVOL})^{8}$. The empirical evidence indicates that: 1) the relationship between effective tax rate and fitness SME investment is negative and statistically significant; and 2) the relationship between risk and fitness SME investment is not statistically significant.

Table 6 presents the results referring to the impact of greater size and greater age on relationships between the determinants: SALES, CF, LEV, AGE, GO, GS, and investment in fitness SMEs.

Comparing the estimated parameters for the relationships between determinants and investment presented in Table 6, with those presented in Table 5, greater size of fitness SMEs means: 1) a greater increase in investment as a consequence of growth opportunities; 2) a lower increase in investment as a consequence of cash flow and government subsidies; and 3) a non-significant impact of debt on investment. Greater age of fitness SMEs means: 1) a lower increase in investment as a consequence of government subsidies; and 2) a nonsignificant impact of growth opportunities on investment.

Table 7 presents the results of the investment determinants for manufacturing SMEs.

Table 6. Investment determinants of fitness SMEs

\begin{tabular}{|c|c|c|c|c|}
\hline & \multicolumn{4}{|c|}{ Dependent Variable: $\mathrm{I}_{\mathrm{i}, \mathrm{t}}$} \\
\hline & I & II & III & IV \\
\hline $\mathrm{D}_{\mathrm{s}} \times$ SALES $_{\mathrm{i}, \mathrm{t}-1}$ & $\begin{array}{l}0.02790^{* *} \\
(0.00645)\end{array}$ & $\begin{array}{c}0.03090^{* *} \\
(0.0074)\end{array}$ & & \\
\hline $\mathrm{D}_{\mathrm{s}} \times \mathrm{CF}_{\mathrm{i}, \mathrm{t}-1}$ & $\begin{array}{l}0.78919^{* *} \\
(0.18723)\end{array}$ & $\begin{array}{l}0.74157^{* *} \\
(0.14526)\end{array}$ & & \\
\hline $\mathrm{D}_{\mathrm{s}} \times \mathrm{LEV}_{\mathrm{i}, \mathrm{t}-1}$ & $\begin{array}{l}-0.05818 \\
(0.07343) \\
\end{array}$ & $\begin{array}{l}-0.04346 \\
(0.07192) \\
\end{array}$ & & \\
\hline $\mathrm{D}_{\mathrm{s}} \times \mathrm{AGE}_{\mathrm{i}, \mathrm{t}-1}$ & & $\begin{array}{c}0.02019 \\
(0.12918) \\
\end{array}$ & & \\
\hline $\mathrm{D}_{\mathrm{s}} \times \mathrm{GO}_{\mathrm{i}, \mathrm{t}-1}$ & & $\begin{array}{l}0.38919^{* *} \\
(0.08640)\end{array}$ & & \\
\hline $\mathrm{D}_{\mathrm{s}} \times \mathrm{GS}_{\mathrm{i}, \mathrm{t}-1}$ & & $\begin{array}{c}0.32399^{*} \\
(0.16018) \\
\end{array}$ & & \\
\hline $\mathrm{D}_{\mathrm{A}} \times$ SALES $_{\mathrm{i}, \mathrm{t}-1}$ & & & $\begin{array}{l}0.02809^{* *} \\
(0.00698)\end{array}$ & $\begin{array}{l}0.02696^{\star *} \\
(0.00890)\end{array}$ \\
\hline
\end{tabular}

8 The mean value of ETR is 0.23747 and the mean value of EVOL is 1.64564 . 
Continued Table 6

\begin{tabular}{|c|c|c|c|c|}
\hline & \multicolumn{4}{|c|}{ Dependent Variable: $I_{i, t}$} \\
\hline & $\mathrm{I}$ & II & III & IV \\
\hline $\mathrm{D}_{\mathrm{A}} \times \mathrm{CF}_{\mathrm{i}, \mathrm{t}-1}$ & & & $\begin{array}{l}1.06171^{\star *} \\
(0.18718)\end{array}$ & $\begin{array}{l}1.08172^{\star *} \\
(0.20198)\end{array}$ \\
\hline $\mathrm{D}_{\mathrm{A}} \times \mathrm{LEV}_{\mathrm{i}, \mathrm{t}-1}$ & & & $\begin{array}{c}-0.18142^{* *} \\
(0.05612)\end{array}$ & $\begin{array}{c}-0.15698^{\star *} \\
(0.04198)\end{array}$ \\
\hline $\mathrm{D}_{\mathrm{A}} \times \mathrm{AGE}_{\mathrm{i}, \mathrm{t}-1}$ & & & & $\begin{array}{c}0.01461 \\
(0.11761)\end{array}$ \\
\hline $\mathrm{D}_{\mathrm{A}} \times \mathrm{GO}_{\mathrm{i}, \mathrm{t}-1}$ & & & & $\begin{array}{c}0.07818 \\
(0.07309)\end{array}$ \\
\hline $\mathrm{D}_{\mathrm{A}} \times \mathrm{GS}_{\mathrm{i}, \mathrm{t}-1}$ & & & & $\begin{array}{c}0.25167^{\star} \\
(0.12340)\end{array}$ \\
\hline CONS & $\begin{array}{l}0.02391^{* *} \\
(0.00559)\end{array}$ & $\begin{array}{l}0.01509^{* *} \\
(0.00513)\end{array}$ & $\begin{array}{l}0.01837^{* *} \\
(0.00490)\end{array}$ & $\begin{array}{l}0.01668^{* *} \\
(0.00478)\end{array}$ \\
\hline $\mathrm{R}^{2}$ & 0.1781 & 0.2590 & 0.2209 & 0.2709 \\
\hline Firms & 182 & 182 & 182 & 182 \\
\hline Observations & 542 & 542 & 542 & 542 \\
\hline
\end{tabular}

Notes: 1 . CONS is the constant of the regressions; 2 . Standard deviations in parenthesis using cluster option; 3. ${ }^{* *}$ statistical significance at $1 \%$ level, ${ }^{*}$ statistical significance at $5 \%$ level; 4 . The estimates include time dummy variables, but are not shown.

Table 7. Investment determinants of manufacturing SMEs

\begin{tabular}{|c|c|c|c|}
\hline & \multicolumn{3}{|c|}{ Dependent Variable: $I_{i, t}$} \\
\hline & $\mathrm{I}$ & II & III \\
\hline SALES $_{\mathrm{i}, \mathrm{t}-1}$ & $\begin{array}{c}0.01066 \\
(0.01289)\end{array}$ & $\begin{array}{c}0.01149 \\
(0.01390)\end{array}$ & $\begin{array}{c}0.01374 \\
(0.01488)\end{array}$ \\
\hline $\mathrm{CF}_{\mathrm{i}, \mathrm{t}-1}$ & $\begin{array}{l}0.65167^{\star *} \\
(0.12839)\end{array}$ & $\begin{array}{l}0.60918^{\star *} \\
(0.10654)\end{array}$ & $\begin{array}{c}0.64631^{\star *} \\
(0.13949)\end{array}$ \\
\hline $\mathrm{LEV}_{\mathrm{i}, \mathrm{t}-1}$ & $\begin{array}{c}0.20192^{\star} \\
(0.09871)\end{array}$ & $\begin{array}{c}0.19445^{\star} \\
(0.09507)\end{array}$ & $\begin{array}{l}0.24959^{* *} \\
(0.07612)\end{array}$ \\
\hline $\mathrm{AGE}_{\mathrm{i}, \mathrm{t}-1}$ & & $\begin{array}{c}-0.06182^{\star} \\
(0.02918)\end{array}$ & $\begin{array}{l}-0.05918^{*} \\
(0.02854)\end{array}$ \\
\hline $\mathrm{GO}_{\mathrm{i}, \mathrm{t}-1}$ & & $\begin{array}{l}0.69812^{\star *} \\
(0.10928)\end{array}$ & $\begin{array}{l}0.71098^{\star *} \\
(0.11433)\end{array}$ \\
\hline $\mathrm{GS}_{\mathrm{i}, \mathrm{t}-1}$ & & $\begin{array}{c}0.11902 \\
(0.40981)\end{array}$ & $\begin{array}{c}0.13291 \\
(0.47818)\end{array}$ \\
\hline $\mathrm{D}_{08-09}$ & & & $\begin{array}{c}-0.10982^{*} \\
(0.05409) \\
\end{array}$ \\
\hline CONS & $\begin{array}{l}0.01543^{* *} \\
(0.00378)\end{array}$ & $\begin{array}{l}0.01394^{* *} \\
(0.00308)\end{array}$ & $\begin{array}{l}0.01092^{\star *} \\
(0.00287)\end{array}$ \\
\hline $\mathrm{R}^{2}$ & 0.1394 & 0.2019 & 0.2394 \\
\hline Firms & 478 & 478 & 478 \\
\hline Observations & 1516 & 1516 & 1516 \\
\hline
\end{tabular}

Notes: 1 . CONS is the constant of the regressions; 2 . Standard deviations in parenthesis using cluster option; 3. ${ }^{* *}$ statistical significance at $1 \%$ level, ${ }^{*}$ statistical significance at $5 \%$ level; 4 . The estimates include time dummy variables, but are not shown. 
Irrespective of the regression estimated, we find that: 1) the relationship between sales and investment is not statistically significant; 2) the relationship between cash flows and investment is positive and statistically significant; and 3) the relationship between debt and investment is positive and statistically significant.

Concerning relationships between the other determinants and investment, we find that: 1) the relationship between age and investment is negative and statistically significant; 2) the relationship between growth opportunities and investment is positive and statistically significant; 3 ) the relationship between government subsidies and investment is not statistically significant; 4) the relationship between the dummy variable representing the financial crisis and investment is negative and statistically significant.

Table 8 below presents the results of the Chow test of the differences in estimated parameters measuring relationships between determinants and investment in fitness SMEs and manufacturing SMEs.

Table 8. Chow test of equality of estimated parameters

\begin{tabular}{|c|c|c|c|}
\hline & \multicolumn{3}{|c|}{ Dependent Variable: $\mathrm{I}_{\mathrm{i}, \mathrm{t}}$} \\
\hline & I & II & III \\
\hline SALES $_{\mathrm{i}, \mathrm{t}-1}$ & $13.30^{\star \star}$ & $12.98^{\star \star}$ & $12.56^{* *}$ \\
\hline $\mathrm{CF}_{\mathrm{i}, \mathrm{t}-1}$ & $11.54^{\star *}$ & $11.23^{* *}$ & $10.12^{\star *}$ \\
\hline $\mathrm{LEV}_{\mathrm{i}, \mathrm{t}-1}$ & $30.18^{\star \star}$ & $28.10^{\star \star}$ & $29.87^{\star \star}$ \\
\hline $\mathrm{AGE}_{\mathrm{i}, \mathrm{t}-1}$ & & $11.14^{\star *}$ & $10.87^{* *}$ \\
\hline $\mathrm{GO}_{\mathrm{i}, \mathrm{t}-1}$ & & $11.90^{\star *}$ & $12.23^{\star *}$ \\
\hline $\mathrm{GS}_{\mathrm{i}, \mathrm{t}-1}$ & & $15.10^{* *}$ & $15.66^{\star *}$ \\
\hline $\mathrm{D}_{08-09}$ & & & $10.76^{* *}$ \\
\hline Global Difference & $22.09^{\star \star}$ & $20.16^{\star *}$ & $19.76^{* *}$ \\
\hline
\end{tabular}

Notes: 1 . Significant at $1 \%$ level.

Irrespective of the regression estimated, for each of the parameters estimated, we find we reject the null hypothesis of equality of estimated parameters measuring relationships between determinants and investment in fitness SMEs and manufacturing SMEs. The results of the total difference of estimated parameters, in each regression, confirm those differences. Based on these results, we can conclude there are significant differences between the investment determinants of fitness SMEs and manufacturing SMEs.

Aiming to determine the effect of the 2008 financial crisis on relationships between the financial variables: CF, LEV, and GS and investment in fitness SMEs, Table 9 presents the results regarding the determinants of fitness SME investment for the periods 2008-2009 and 2004-2007.

The empirical evidence indicates that: 1) in the periods 2008-2009 and 2004-2007, the relationships between cash flow and investment in fitness SMEs are positive and statistically significant; 2) in the periods 2008-2009 and 2004-2007, the relationships between debt and investment in fitness SMEs are negative and statistically significant; and 3) in the periods 2008-2009 and 2004-2007, the relationships between government subsidies and investment in fitness SMEs are positive and statistically significant. However, the magnitude of estimated 
Table 9. Investment determinants of fitness SMEs in periods 2008-2009 and 2004-2007

\begin{tabular}{|c|c|c|c|c|c|c|}
\hline & \multicolumn{6}{|c|}{ Dependent Variable: $I_{i, t}$} \\
\hline & \multicolumn{2}{|c|}{ Period 2008-2009 } & \multicolumn{2}{|c|}{ Period 2004-2007 } & \multicolumn{2}{|c|}{ Chow Test } \\
\hline & I & II & I & II & $\mathrm{I}$ & II \\
\hline $\mathrm{CF}_{\mathrm{i}, \mathrm{t}-1}$ & $\begin{array}{l}1.65362^{\star \star} \\
(0.28199)\end{array}$ & $\begin{array}{l}1.62831^{\star *} \\
(0.27618)\end{array}$ & $\begin{array}{l}0.63901^{\star *} \\
(0.12388)\end{array}$ & $\begin{array}{l}0.61842^{* *} \\
(0.11784)\end{array}$ & $17.90^{\star \star}$ & $17.66^{\star *}$ \\
\hline $\mathrm{LEV}_{\mathrm{i}, \mathrm{t}-1}$ & $\begin{array}{c}-0.26471^{\star *} \\
(0.08828)\end{array}$ & $\begin{array}{c}-0.28812^{\star *} \\
(0.09532)\end{array}$ & $\begin{array}{c}-0.06178^{\star} \\
(0.02912)\end{array}$ & $\begin{array}{c}-0.06263^{*} \\
(0.03012)\end{array}$ & $13.40^{\star \star}$ & $14.02^{\star *}$ \\
\hline $\mathrm{GS}_{\mathrm{i}, \mathrm{t}-1}$ & $\begin{array}{l}1.02165^{* *} \\
(0.25647)\end{array}$ & $\begin{array}{l}1.04112^{\star *} \\
(0.27623)\end{array}$ & $\begin{array}{l}0.37182^{\star *} \\
(0.09182)\end{array}$ & $\begin{array}{l}0.35077^{* *} \\
(0.08610)\end{array}$ & $14.47^{\star \star}$ & $15.58^{\star *}$ \\
\hline SALES $_{i, t}$ & & $\begin{array}{l}0.02178^{\star \star} \\
(0.00561)\end{array}$ & & $\begin{array}{l}0.02998^{* *} \\
(0.00712)\end{array}$ & & \\
\hline $\mathrm{AGE}_{\mathrm{i}, \mathrm{t}}$ & & $\begin{array}{c}0.01225 \\
(0.08918)\end{array}$ & & $\begin{array}{c}0.02189 \\
(0.12056)\end{array}$ & & \\
\hline $\mathrm{GO}_{\mathrm{i}, \mathrm{t}}$ & & $\begin{array}{c}0.06194 \\
(0.03817)\end{array}$ & & $\begin{array}{l}0.31949^{* *} \\
(0.07154)\end{array}$ & & \\
\hline CONS & $\begin{array}{l}0.04516^{* *} \\
(0.01118)\end{array}$ & $\begin{array}{l}0.01961^{\star *} \\
(0.00612)\end{array}$ & $\begin{array}{l}0.03841^{\star *} \\
(0.00981)\end{array}$ & $\begin{array}{l}0.01491^{*} \\
(0.00381)\end{array}$ & & \\
\hline $\mathrm{R}^{2}$ & 0.1891 & 0.2219 & 0.2022 & 0.2716 & & \\
\hline Firms & 155 & 152 & 144 & 144 & & \\
\hline Observations & 310 & 310 & 387 & 387 & & \\
\hline
\end{tabular}

Notes: 1 . CONS is the constant of the regressions. 2. Standard deviations in parenthesis using cluster option. 3. ${ }^{*}$ statistical significance at $1 \%$ level; ${ }^{*}$ statistical significance at $5 \%$ level. 4 . The estimates include time dummy variables, but are not shown.

parameters is found to be greater in the period 2008-2009 than in the period 2004-2007, which reveals that cash flow and government subsidies are especially relevant for increased investment in fitness SMEs in the period 2008-2009, with debt being a particularly restrictive determinant of fitness SME investment in the period 2008-2009. The test results of difference for each of the parameters estimated confirm the differences.

\section{Discussion of the results}

We find a positive and statistically significant relationship between sales and investment. Therefore, if sales increase, investment increases, with investment diminishing if sales fall. So we reject hypothesis $\mathrm{H} 1$, since sales are a positive determinant of investment in fitness SMEs. This empirical evidence partially corroborates the arguments, and results, of Eisner (1963) and Chirinko (1993), since sales are an explanatory determinant of investment, but they are not predominant over other possible investment variables, since, for example, cash flow and debt are also explanatory variables of investment. Nevertheless, given the positive relationship between sales and investment, we cannot consider Neoclassical theory irrelevant in explaining the investment decisions of Portuguese fitness SMEs.

In manufacturing SMEs, we find a statistically insignificant relationship between sales and investment. Unlike the case of fitness SMEs, Neoclassical theory is irrelevant in explaining 
the investment decisions of manufacturing SMEs. It is interesting to note that while fitness SMEs are on average smaller than manufacturing SMEs, the former adjust their investment as a function of sales, contradicting the idea that in small firms sales will be more important to cope with treasury difficulties than to finance investment, i.e. contradicting the idea that Neoclassical theory is more relevant in explaining the investment decisions of large firms than in explaining those of small ones.

The relationship between cash flow and investment is positive and statistically significant. Therefore, we cannot reject hypothesis $\mathrm{H} 2$, since cash flow is important for investment in Portuguese fitness SMEs. Based on this result, we can consider the assumptions of Free Cash Flow theory as valid in explaining the investment decisions of Portuguese fitness SMEs. We also find that greater size of fitness SMEs means less impact of cash flow on investment, which reveals that Free Cash Flow theory becomes more relevant in explaining the investment decisions of fitness SMEs the smaller their size.

This result agrees with the conclusions of Fazzari et al. (1988), since terms of finance are relevant for the investment decisions of firms in general, and small firms in particular. The positive relationship between cash flow and investment corroborates the empirical evidence obtained by Fazzari et al. (1988), Fazzari and Petersen (1993), Kaplan and Zingales (1997, 2000), Mizen and Vermeulen (2004), Hung and Kuo (2011).

The fact that cash flow is important in explaining investment in Portuguese fitness SMEs, that importance being greater the smaller their size, reveals the importance problems of information asymmetry in relationships between owners/managers and creditors may represent in the activities of this type of firm.

Although cash flow is a determinant stimulating investment in manufacturing SMEs, we find it is relatively less important in explaining investment than in fitness SMEs. The fact that fitness SMEs are on average smaller than manufacturing SMEs may contribute to internal finance being more relevant in explaining investment in the former, due to this type of firm's greater difficulty in accessing external funding. Based on these results we can conclude that Free Cash Flow theory is of greater relative importance in explaining the investment decisions of fitness SMEs, than in explaining those of manufacturing SMEs.

We find a negative relationship between debt and investment in Portuguese fitness SMEs. Based on this result, we cannot reject the previously formulated hypothesis $\mathrm{H} 3$, since debt is a restrictive determinant of investment in Portuguese fitness SMEs. This result indicates that the assumptions of Agency theory, namely problems of information asymmetry in the relationships formed between owners/managers and creditors, can be considered valid in explaining the investment decisions of Portuguese fitness SMEs.

In situations of information asymmetry in relationships between owners/managers and creditors, the latter can limit the amount of credit or increase its cost, which may explain the negative relationship identified between debt and investment in Portuguese fitness SMEs. Indeed the limited size of these firms can make it impossible in many situations to provide creditors with reliable information. Due to the great uncertainty associated with small firms' activities together with the lack of reliable information, creditors could hinder access to debt through raising its cost, this corresponding to debt's negative influence on investment.

Considering that Portuguese fitness SMEs are very small firms, the negative relationship identified between debt and investment in those firms may be the consequence of their 
particular difficulty in obtaining external finance, given their small size and consequently lesser reputation in the market and greater likelihood of bankruptcy. The importance of size in explaining the relationship between debt and investment is revealed by the fact that greater size of fitness SMEs contributes to the impact of debt on investment being not significant, Agency theory seeming to be not relevant in explaining the investment decisions of fitness SMEs the greater their size.

The negative relationship between debt and investment agrees with the empirical evidence obtained by Lang et al. (1996), Aivazian et al. (2005), Ahn et al. (2006) and Firth et al. (2008). In manufacturing SMEs we find debt to be a determinant stimulating investment. This result is particularly relevant because it indicates that the greater size of manufacturing SMEs, compared to fitness SMEs, may contribute to diminished information asymmetry in relationships with creditors, due to greater size meaning less likelihood of bankruptcy.

We find that Neoclassical, Free Cash Flow and Agency theories are not necessarily exclusive in explaining the investment decisions of Portuguese fitness SMEs. Indeed, although the problems of information asymmetry explicit in relationships between owners/managers and creditors seem to be particularly relevant, from the fact of cash flow contributing to increased investment and debt meaning less investment, the importance of sales as a determinant of investment in Portuguese fitness SMEs cannot be ignored.

As for relationships between the other determinants considered in this study and investment in Portuguese fitness SMEs, the one between age and investment is not statistically significant, and those between growth opportunities and investment and between government subsidies and investment are positive and statistically significant.

The statistically insignificant relationship between age and investment lets us reject the previously formulated hypothesis H41, since greater age of Portuguese fitness SMEs does not mean increased levels of investment. The fact that the age of Portuguese fitness SMEs does not mean increased investment as a consequence of having been able to get over initial financial restrictions and the reputation effect conferred by age, may be related to the need for considerable investment in fixed assets in the early periods of the life cycle, since the initial cost of fixed assets is particularly important in the activities of this type of firm.

In manufacturing SMEs we find age to be a restrictive determinant of investment. As the age of manufacturing SMEs increases, the lower is the investment. This result reveals the greater relative importance of investment in fixed assets in this type of SME, compared to the case of fitness SMEs.

The relationship between growth opportunities and investment is positive and statistically significant. Therefore, we cannot reject the previously formulated hypothesis H42, since growth opportunities are a positive determinant of investment in Portuguese fitness SMEs.

Creditors may recognize good growth opportunities, lessening the difficulties in granting credit to small firms (Carpenter, Guariglia 2008), and young, small firms may have good growth opportunities, increasing investment to take advantage of them (Fagiolo, Luzzi 2006). However, the positive effect is more significant in larger fitness SMEs, but insignificant when considering older fitness SMEs, revealing that whereas greater size can be a fundamental characteristic for creditors recognizing growth opportunities in fitness SMEs, this does not happen with greater age. 
It also stands out that growth opportunities are of greater relative importance for investment in manufacturing SMEs than for investment in fitness SMEs. This evidence indicates, firstly, that creditors can recognize more effectively the growth opportunities of manufacturing SMEs, and secondly, that there is a greater association between intangible assets and fixed assets in manufacturing SMEs than in fitness SMEs.

The relationship between government subsidies and investment is positive and statistically significant. Based on this result, we cannot reject the previously formulated hypothesis $\mathrm{H} 43$, since government subsidies are a positive determinant of investment in Portuguese fitness SMEs.

Government subsidies may be especially relevant for small firms in overcoming possible financing restrictions. The lesser importance of government subsidies for investment in larger, older fitness SMEs emphasizes the importance of this type of support the smaller and younger they are. This result reveals the importance of government subsidies for small, young fitness SMEs, firms that could be very restricted financially due to the limited capacity to generate internal funding and the difficulty in accessing external finance.

The fact that government subsidies do not stimulate investment in manufacturing SMEs, while being a positive determinant of investment in fitness SMEs, indicates that government subsidies can be particularly relevant for increased investment in small, young service firms such as fitness SMEs. The smaller size and young age of fitness SMEs, compared to manufacturing SMEs, could contribute to this type of support being particularly important for investment in the former, since whereas manufacturing SMEs seem to finance their investment through debt, this does not happen in fitness SMEs.

We find a negative relationship between the dummy variable representing the financial crisis of 2008 and investment in fitness SMEs. This being the case, we conclude that the financial crisis of 2008 is a restrictive determinant of fitness SME investment, and so we cannot reject the previously formulated hypothesis $\mathrm{H} 44$.

This result indicates that the financial crisis of 2008 meant diminished investment in fitness SMEs, probably due to worsening terms of credit available to them in that period and the following one. Also in the case of manufacturing SMEs, a negative relationship is found between the dummy variable representing the financial crisis of 2008 and investment. Nevertheless, in comparative terms, the negative impact of the financial crisis of 2008 on investment in fitness SMEs is of a greater magnitude than on investment in manufacturing SMEs. This finding reinforces the idea that terms of credit for fitness SMEs may have been harsher than those applied to their manufacturing counterparts.

The financial crisis of 2008 contributes to internal finance and government subsidies being of greater relative importance for increased investment in fitness SMEs, and also to debt being of greater relative importance for diminished investment. Therefore, we cannot reject the previously formulated hypotheses $\mathrm{H} 45$ and H46. This empirical evidence is particularly relevant as it indicates that the financial crisis of 2008 has a particularly restrictive effect on fitness SMEs' access to external finance as a way of funding investment, internal finance and government subsidies being of greater relative importance for increased investment in this type of firm. The fact of the financial crisis of 2008 contributing to greater relevance of cash flow for increased investment and greater relevance of debt for reduced investment, reveals 
that the financial crisis contributes to greater relevance of Free Cash Flow and Agency theories in explaining the investment decisions of fitness SMEs.

We also find that a higher level of tax paid by fitness SMEs means lower levels of investment. Taxes paid are a restrictive determinant of investment in fitness SMEs, probably due to less capacity to finance their investment opportunities. Level of risk appears not to influence fitness SME investment. Greater operational risk, and consequently greater likelihood of bankruptcy, does not mean diminished investment in fitness SMEs, i.e. apparently, fitness SMEs with a greater probability of bankruptcy does not reduce their levels of investment.

\section{Conclusion and implications}

Based on a sample of 182 Portuguese fitness SMEs this paper studies the investment determinants of Portuguese fitness SMEs. The paper contributes to the literature by showing that the main explanatory theories of firm investment are not necessarily mutually exclusive in explaining the investment decisions of small and young service SMEs, more specifically, fitness SMEs, because: 1) adjustment of investment is found to be a function of sales, corroborating the assumptions of Neoclassical theory; 2) cash flow is relevant for increased investment, agreeing with the assumptions of Free Cash Flow theory; and 3) debt is a restrictive determinant of investment, revealing the importance of problems of information asymmetry in relationships between owners/managers and creditors, which corroborates the assumptions of Agency theory. More specifically, the paper contributes to the literature showing that Neoclassical theory is relevant in explaining the investment decisions of small, young service SMEs, which reveals that small size and young age do not always contribute to firms failing to adjust investment as a function of sales.

The fact that Portuguese fitness SMEs adjust investment as a function of cash flow and that debt restricts investment reveals the importance of problems of information asymmetry in relationships between the owners/managers of these Portuguese fitness SMEs and creditors. However, the fact that Portuguese fitness SMEs adjust their level of investment as a function of sales illustrates that this type of firm does not adjust investment only as a function of financial characteristics, but also considering the possibilities for expansion in operating markets in investment decisions.

It stands out, firstly, that greater size is of particular importance for Free Cash Flow theory being less relevant, and Agency theory being not relevant, in explaining the investment decisions of fitness SMEs. Secondly, Neoclassical theory is seen to be relevant in explaining the investment decisions of fitness SMEs, something which is not found in manufacturing SMEs, with Free Cash Flow and Agency theories also being more relevant in explaining the investment decisions of fitness SMEs than in explaining those of manufacturing SMEs.

As for the other investment determinants used in this study, growth opportunities and government subsidies are found to be positive determinants of investment, the financial crisis of 2008 has a negative influence on investment, and age is neither a positive nor restrictive determinant of investment in Portuguese fitness SMEs. Firstly, the fact that Portuguese fitness SMEs adjust investment as a function of growth opportunities reinforces the idea that this type of firm does not only consider financial conditions as investment determinants. Secondly, 
government subsidies are a positive determinant of investment, indicating that when internal finance is insufficient, due to the difficulties in accessing external finance, public funding could be fundamental for financing investment in Portuguese fitness SMEs. Thirdly, the fact that the financial crisis of 2008 has a negative impact on fitness SME investment indicates that when internal funding is insufficient, in periods of financial crisis, conditions for fitness SMEs accessing credit could be particularly adverse. We also find that the financial crisis of 2008 contributes to cash flow and government subsidies being of greater relative importance for increased investment, and to debt being of greater relative importance for diminished investment in fitness SMEs. These results strengthen the notion that the financial crisis of 2008, besides restricting investment, also contributes to fitness SME investment being more dependent on internal finance and government subsidies and less dependent on debt. In addition, higher levels of taxes paid are found to mean diminished investment in fitness SMEs, with operational risk not contributing to either an increase or reduction of investment in fitness SMEs.

Fitness SMEs provide important services of preventive medicine to improve the population's health and well-being. However, in most cases, their small size and young age may affect their strategies for implementation in their operating markets. The empirical evidence obtained in this study of Portuguese fitness SMEs allows us to suggest the following measures for economic policy in general, and industrial policy in particular: 1) considering that debt is a restrictive determinant of investment, with cash flow and government subsidies being positive determinants, we suggest reinforcing government subsidies for Portuguese fitness SMEs with particular difficulties in accessing external finance and without the internal finance necessary to fund their good investment opportunities. At times of financial crisis, when internal finance is insufficient, strengthening government subsidies could be particularly relevant for increased investment in fitness SMEs; and 2) considering that sales and growth opportunities are positive determinants of investment, specific financial support is suggested for Portuguese fitness SMEs with good investment and growth projects, but with difficulty in financing those projects.

In future research, we intend to study specifically the capital structure of Portuguese fitness SMEs, so as to understand how the specific characteristics of these firms affect, or do not affect, their financing decisions. Furthermore, we intend to carry out cross-cultural comparisons within the country, so as to ascertain whether the different cultural situations in Portuguese regions have an influence on the relationships found between determinants and investment in fitness SMEs.

\section{References}

Ahn, S.; Denis, D.; Denis, D. 2006. Leverage and investment in diversified firms, Journal of Financial Economics 79(2): 317-337. http://dx.doi.org/10.1016/j.jfineco.2005.03.002

Aivazian, V.; Ge, Y.; Qiu J. 2005. The impact of leverage on firm investment: Canadian evidence, Journal of Corporate Finance 11(1-2): 277-291. http://dx.doi.org/10.1016/S0929-1199(03)00062-2

Andersen-Hanley, C.; Nimon, J.; Western, S. 2010. Cognitive health benefits of strengthening exercise for community-dwelling older adults, Journal of Clinical and Experimental Neuropsychology 32(9): 996-1001. http://dx.doi.org/10.1080/13803391003662702 
Ang, J. 1991. Small business uniqueness and the theory of financial management, Journal of Small Business Finance 1(1): 1-13.

Antão, P.; Bonfim, D. 2012. The dynamics of capital structure decisions, Working Papers No 201206 [online], [cited 23 April 2013]. Economics and Research Department, Banco de Portugal, Portugal. Available from Internet: http://www.bportugal.pt/en-US/BdP\%20Publications\%20Research/wp201206.pdf

Arellano, M.; Bond, S. 1991. Some tests of specification for panel data: Monte Carlo evidence and an application to employment equations, Review of Economic Studies 58(2): 277-297. http://dx.doi.org/10.2307/2297968

Ascioglu, A.; Hegde, S.; McDermott, J. 2008. Information asymmetry and investment-cash flow sensitivity, Journal of Banking \& Finance 32(6): 1036-1048. http://dx.doi.org/10.1016/j.jbankfin.2007.09.018

Baker, T.; Gedajlovic, E.; Lubatkin, M. 2005. A framework for comparing entrepreneurship across nations, Journal of International Business Studies 36(5): 492-504.

http://dx.doi.org/10.1057/palgrave.jibs.8400153

Beck, T.; Demirgüç-Kunt, A.; Laeven, L.; Maksimovic, V. 2006. The determinants of financing obstacles, Journal of International Money \& Finance 25(6): 932-952. http://dx.doi.org/10.1016/j.jimonfin.2006.07.005

Brown, J.; Fazzari, S.; Petersen, B. 2009. Financing innovation and growth: cash flow, external equity and the 1990s R\&D boom, The Journal of Finance 64(1): 151-185. http://dx.doi.org/10.1111/j.1540-6261.2008.01431.x

Carpenter, R.; Guariglia, A. 2008. Cash-flows, investment and investment opportunities: new tests using UK panel data, Journal of Banking and Finance 32(9): 1894-1906. http://dx.doi.org/10.1016/j.jbankfin.2007.12.014

Chirinko, S. 1993. Business fixed investment spending: modelling strategies, empirical results and policy implications, Journal of Economics Literature 31(4): 1875-1911.

Cho, I.; Park, H.; Choi, J. 2011. The impact of diversity of innovation channels on innovation performance in service firms, Service Business 5(3): 277-294. http://dx.doi.org/10.1007/s11628-011-0114

Cho, I.; Park, H.; Kim, J. 2012. The moderating effect of innovation protection mechanisms on the competitiveness of service firms, Service Business 6(3): 369-386. http://dx.doi.org/10.1007/s11628-012-0140-3

Dale, S.; Godinet, S.; Kearse, N.; Field, A. 2009. The future of fitness, a White Paper. Ed. Les Mills International Ltd, 1-21.

Devereux, M.; Schiantarelli, F. 1990. Investment, financial factors, and cash flow: evidence from U.K. panel data. Asymmetric Information, Corporate Finance, and Investment, University of Chicago Press, 279-306.

Diamond, D. 1989. Financial intermediation and delegated monitoring, Review of Economic Studies 51(3): 393-414. http://dx.doi.org/10.2307/2297430

Eisner, R. 1963. Investment: fact and fancy, American Economic Review 53(2): 237-246. http://www.jstor.org/stable/1823867

Evans, D.; Jovanovic, B. 1989. An estimated model of entrepreneurial choice under liquidity constraints, Journal of Political Economics 97(4): 808-827. http://dx.doi.org/10.1086/261629

Fagiolo, G., Luzzi, A. 2006. Do liquidity constraints matter in explaining firm size and growth? Some evidence from the Italian manufacturing industry, Industrial and Corporate Change 15(1): 1-39. http://dx.doi.org/10.1093/icc/dtj001

Fazzari, S.; Hubbard, G.; Petersen, B. 1988. Financing constraints and corporate investment, Brookings Papers on Economics Activity 1(1): 141-195. http://dx.doi.org/10.2307/2534426

Fazzari, S.; Petersen, B. 1993. Working capital and fixed investment: new evidence on financing constraints, Rand Journal of Economics 24(3): 328-342. http://dx.doi.org/10.2307/2555961 
Firth, M.; Lin, C.; Wong, S. 2008. Leverage and investment under a state-owned bank lending environment: evidence from China, Journal of Corporate Finance 14(5): 642-653.

http://dx.doi.org/10.1016/j.jcorpfin.2008.08.002

Garber, C.; Blissmer, B.; Deschenes, M.; Franklin, B.; Lamonte, M.; Lee, I.-M.; Nieman, D.; Swain, D. 2011. Quantity and quality of exercise for developing and maintaining cardiorespiratory, musculoskeletal, and neuromotor fitness in apparently healthy adults: guidance for prescribing exercise, Medicine \& Science in Sports \& Exercise 43(7): 1334-1359. http://dx.doi.org/10.1249/MSS.0b013e318213fefb

Gilchrist, S.; Himmelberg, P. 1995. Evidence on the role of cash-flows for investment, Journal of Monetary Economics 36: 541-572. http://dx.doi.org/10.1016/0304-3932(95)01223-0

Gujarati, D.; Porter, D. 2010. Essentials of econometrics. $4^{\text {th }}$ ed. New York: McGraw - Hill International, $1-547$.

Hall, R.; Jorgenson, D. 1967. Tax policy and investment behaviour, American Economic Review 57(3): 391-414.

Hung, J.-H.; Kuo, Y.-P. 2011. The effect of family control on investment-cash flow sensitivity, Applied Financial Economics 21(12): 897-904. http://dx.doi.org/10.1080/09603107.2010.539533

Jensen, M. 1986. Agency costs of free cash-flow, corporate finance and takeovers, AEA Papers and Proceedings 76(2): 383-393.

Jensen, M.; Meckling, W. 1976. Theory of the firm: managerial behaviour, agency costs and ownership structure, Journal of Financial Economics 3(4): 305-360. http://dx.doi.org/10.1016/0304-405X(76)90026-X

Jorgenson, D. 1971. Econometric studies of investment behaviour: a survey, Journal of Economics Literature 9(4): 1111-1147. http://www.jstor.org/stable/2721137

Junlu, M.; Zeguang, L.; Qunyong, W. 2009. Financial constraints, agency cost and firm's investment behavior: evidence from listed firms of China, Frontiers of Economics in China 4(3): 384-405. http://dx.doi.org/10-1007/s11459-009-0021-4

Kaplan, S.; Zingales, L. 1997. Do financing constraints explain why investment is correlated with cash-flow?, Quarterly Journal of Economics 112(1): 169-215. http://dx.doi.org/10.1162/003355397555163

Kaplan, S.; Zingales, L. 2000. Investment cash-flow sensitivities are not valid measures of financing constraints, Quarterly Journal of Economics 115(2): 707-712. http://dx.doi.org/10.1162/003355300554782

Lang, L.; Ofek, E.; Stulz, R. 1996. Leverage, investment, and firm growth, Journal of Financial Economics 40(1): 3-29. http://dx.doi.org/10.1016/0304-405X(95)00842-3

Lee, S.; Ratti, R. 2008. Bank concentration and financial constraints on firm-level in Europe [online], [cited 23 April 2013]. Department of Economics, University of Missouri, Columbia. Available from Internet: http://www.businessandeconomics.mq.edu.au/our_departments/Economics/Econ_docs/ research_seminars/2007_research_seminars/ratti_BankConcentration.pdf

Manolova, T.; Eunni, R.; Gyoshev, B. 2008. Institutional environments for entrepreneurship: evidence from emerging economies in eastern Europe, Entrepreneurship Theory and Practice 32(1): 203-218. http://dx.doi.org/10.1111/j.1540-6520.2007.00222.x

Mateev, M.; Anastasov, Y. 2011. On the growth of small and medium sized enterprises in Central and Eastern Europe: a dynamic panel analysis, The Banking and Finance Review 3(2): 81-104. http://www.bankingandfinancereview.com/bfr/index.php/bfr/article/view/193

Mateev, M.; Tsekov, I. 2012. Do Central and Eastern European countries posses FDI advantages to more developed Western Countries? [online], [cited 23 April 2013]. Available from Internet: http://ssrn. com/abstract $=2139361$

Mizen, P.; Vermeulen, P. 2004. Corporate investment and financial constraints: what drives the relationship? [online], [cited 23 April 2013]. University of Nottingham and European Centre Bank. Available from Internet: http://www.ecb.europa.eu/pub/pdf/scpwps/ecbwp485.pdf 
Modigliani, F.; Miller, M. 1958. The cost of capital, corporation finance and the theory of investment, American Economics Review 48(3): 261-297. http://www.jstor.org/stable/1809766

Moyen, N. 2004. Investment cash-flow sensitivities: constrained versus unconstrained firms, Journal of Finance 59(5): 2061-2092. http://dx.doi.org/10.1111/j.1540-6261.2004.00692.x

Myers, S. 1977. The determinants of corporate borrowing, Journal of Financial Economics 5(2): 147-175. http://dx.doi.org/10.1016/0304-405X(77)90015-0

Oliner, S.; Rudebusch, G. 1992. Sources of the financing hierarchy for business investment, The Review of Economics and Statistics 74(4): 643-654. http://www.jstor.org/stable/2109378

Peng, M. 2003. Institutional transitions and strategic choices, Academy of Management Review 28(2):275-296. http://dx.doi.org/10.2307/30040713

Petersen, M.; Rajan, R. 1995. The effect of credit market competition on lending relationship, Quarterly Journal of Economics 110(2): 407-443. http://dx.doi.org/10.2307/2118445

Roofthooft, W. 2010. Customer equity: a creative tool for SMEs in the services industry: how small and medium enterprises can win the battle for innovation, Service Business 4(1): 37-48.

http://dx.doi.org/10.10077s11628-009-0082-6

Serrasqueiro, Z.; Armada, M.; Maçãs Nunes, P. 2011. Pecking order theory versus trade-off theory: are service SMEs' capital structure decisions different?, Service Business 5(4): 381-409.

http://dx.doi.org/10-1007/s11628-011-0119-5

Silva, F.; Carreira, C. 2009. No deep pockets: some stylized results on firms' financial constraints [online], [cited 23 April 2013], Estudos do GEMF 06/2009. Coimbra: GEMF, Universidade de Coimbra. Available from Internet: http://gemf.fe.uc.pt/workingpapers/abstracts/2009/resumo2009_06.htm

Smallbone, D.; Welter, F. 2006. Conceptualising entrepreneurship in a transition context, International Journal of Entrepreneurship and Small Business 3(2): 190-206. http://dx.doi.org/10.1504/IJESB.2006.008928

Smallbone, D.; Welter, F.; Voytovich, A.; Egorov, I. 2010. Government and entrepreneurship in transition economies: the case of small firms in business services in Ukraine, The Services Industries Journal 30(5): 655-670. http://dx.doi.org/10.1080/02642060802253876

Stiglitz, J.; Weiss, A. 1981. Credit rationing in markets with imperfect information, American Economic Review 71(3): 393-410. http://www.jstor.org/stable/1802787

Stulz, R. 1990. Managerial discretion and optimal financing policies, Journal of Financial Economics 26(1): 3-27. http://dx.doi.org/10.1016/0304-405X(90)90011-N

Sun, J.; Nobuyoshi, Y. 2009. Regional disparities and investment-cash flow sensitivity: evidence from Chinese listed firms, Pacific Economic Review 14(5): 657-667. http://dx.doi.org/10.1111/j.1468-0106.2009.00477.x

Vermeulen, P. 2002. Business fixed investment: evidence of a financial accelerator in Europe, Oxford Bulletin of Economics and Statistics 64(3): 213-231. http://dx.doi.org/10.1111/1468-0084.00020

Vermoesen, V.; Deloof, M.; Laveren, E. 2013. Long-term debt maturity and financial constraints of SMEs during the global crisis, Small Business Economics 41(2): 433-448. http://dx.doi.org/10.1007/s1187-012-9435-y

$\mathrm{Xu}$, B. 1998. A reestimation of the Evans-Jovanovic entrepreneurial choice model, Economics Letters 58(1): 91-95. http://dx.doi.org/10.1016/S0165-1765(97)00255-3

Zwiebel, J. 1996. Dynamics capital structure under management entrenchment, American Economics Review 86(5): 1197-1215. http://www.jstor.org/stable/2118286 
APPENDIX A.

Descriptive statistics and correlation matrix - manufacturing SMEs

Table A1. Descriptive statistics

\begin{tabular}{lccccccc}
\hline \multicolumn{1}{c}{ Variable } & Firms & Observations & Mean & Median & S.D. & Min & Max \\
\hline $\mathrm{I}_{\mathrm{i}, \mathrm{t}}$ & 478 & 1994 & 0.1430 & 0.1309 & 0.3174 & -0.7183 & 7.9102 \\
\hline SALES $_{\mathrm{i}, \mathrm{t}}$ & 478 & 1994 & 14.714 & 14.598 & 1.9492 & 9.8617 & 17.723 \\
\hline $\mathrm{CF}_{\mathrm{i}, \mathrm{t}}$ & 478 & 1994 & 0.0749 & 0.0769 & 0.1983 & -1.6494 & 1.2083 \\
\hline $\mathrm{LEV}_{\mathrm{i}, \mathrm{t}}$ & 478 & 1994 & 0.6283 & 0.4981 & 0.2092 & 0 & 0.9438 \\
\hline $\mathrm{AGE}_{\mathrm{i}, \mathrm{t}}$ & 478 & 1994 & 2.7333 & 2.6390 & 0.6838 & 0 & 4.6821 \\
\hline $\mathrm{GO}_{\mathrm{i}, \mathrm{t}}$ & 478 & 1994 & 0.0130 & 0.0034 & 0.0498 & 0 & 0.7593 \\
\hline $\mathrm{GS}_{\mathrm{i}, \mathrm{t}}$ & 478 & 1994 & 0.0085 & 0 & 0.0348 & 0 & 0.4594 \\
\hline $\mathrm{D}_{08-09}$ & 478 & 1994 & 0.3766 & 0 & 0.4846 & 0 & 1 \\
\hline & & & & & & &
\end{tabular}

Table A2. Correlation matrix

\begin{tabular}{|c|c|c|c|c|c|c|c|c|}
\hline & $\mathrm{I}_{\mathrm{i}, \mathrm{t}}$ & SALES $_{\mathrm{i}, \mathrm{t}-1}$ & $\mathrm{CF}_{\mathrm{i}, \mathrm{t}-1}$ & $\mathrm{LEV}_{\mathrm{i}, \mathrm{t}-1}$ & $\mathrm{AGE}_{\mathrm{i}, \mathrm{t}-1}$ & $\mathrm{GO}_{\mathrm{i}, \mathrm{t}-1}$ & $\mathrm{GS}_{\mathrm{i}, \mathrm{t}-1}$ & $\mathrm{D}_{08-09}$ \\
\hline $\mathrm{I}_{\mathrm{i}, \mathrm{t}}$ & 1 & & & & & & & \\
\hline SALES $_{\mathrm{i}, \mathrm{t}-1}$ & $0.035^{*}$ & 1 & & & & & & \\
\hline $\mathrm{CF}_{\mathrm{i}, \mathrm{t}-1}$ & $0.219^{\star *}$ & $0.256^{\star \star}$ & 1 & & & & & \\
\hline $\mathrm{LEV}_{\mathrm{i}, \mathrm{t}-1}$ & $0.156^{\star *}$ & $0.098^{\star *}$ & $-0.239^{\star *}$ & 1 & & & & \\
\hline $\mathrm{AGE}_{\mathrm{i}, \mathrm{t}-1}$ & $-0.109^{\star *}$ & $0.030^{*}$ & $0.140^{* *}$ & $0.278^{\star *}$ & 1 & & & \\
\hline $\mathrm{GO}_{\mathrm{i}, \mathrm{t}-1}$ & $0.129^{\star *}$ & $0.087^{\star *}$ & $0.135^{* *}$ & $-0.112^{\star *}$ & -0.013 & 1 & & \\
\hline $\mathrm{GS}_{\mathrm{i}, \mathrm{t}-1}$ & -0.010 & 0.011 & $-0.106^{\star *}$ & $0.098^{\star *}$ & $-0.132^{\star *}$ & $0.071^{\star *}$ & 1 & \\
\hline $\mathrm{D}_{08-09}$ & $-0.078^{\star *}$ & $-0.089^{\star *}$ & $-0.220^{\star *}$ & $-0.286^{* *}$ & $0.154^{\star *}$ & 0.011 & $0.128^{* *}$ & 1 \\
\hline
\end{tabular}

Notes: ${ }^{*}$ Statistical significant at $1 \%$ level; ${ }^{*}$ Statistical Significant at $5 \%$ level.

\section{APPENDIX B.}

\section{Investment determinants of fitness SMEs - alternative estimations}

Table B1. Investment determinants of fitness SMEs - alternative measure of dependent variable, lagged explanatory variables and OLS regressions

\begin{tabular}{|c|c|c|c|}
\hline & \multicolumn{3}{|c|}{ Dependent Variable: $I_{i, t}$} \\
\hline & I & II & III \\
\hline $\mathrm{I}_{\mathrm{i}, \mathrm{t}-1}$ & $\begin{array}{l}0.11891^{\star *} \\
(0.03049)\end{array}$ & $\begin{array}{l}0.10293^{\star *} \\
(0.02718)\end{array}$ & $\begin{array}{l}0.12955^{\star *} \\
(0.03411)\end{array}$ \\
\hline SALES $_{i, t-2}$ & $\begin{array}{l}0.01517^{\star} \\
(0.00742)\end{array}$ & $\begin{array}{c}0.01819^{*} \\
(0.00876)\end{array}$ & $\begin{array}{l}0.01761^{\star} \\
(0.00815)\end{array}$ \\
\hline $\mathrm{CF}_{\mathrm{i}, \mathrm{t}-2}$ & $\begin{array}{l}1.10981^{\star *} \\
(0.17896)\end{array}$ & $\begin{array}{l}1.15169^{\star *} \\
(0.21589)\end{array}$ & $\begin{array}{l}1.03728^{\star *} \\
(0.17652)\end{array}$ \\
\hline $\mathrm{LEV}_{\mathrm{i}, \mathrm{t}-2}$ & $\begin{array}{c}-0.12998^{*} \\
(0.06276) \\
\end{array}$ & $\begin{array}{l}-0.10762^{*} \\
(0.05255) \\
\end{array}$ & $\begin{array}{c}-0.15412^{* *} \\
(0.04471) \\
\end{array}$ \\
\hline $\mathrm{AGE}_{\mathrm{i}, \mathrm{t}-2}$ & & $\begin{array}{c}0.01167 \\
(0.15268)\end{array}$ & $\begin{array}{c}0.01353 \\
(0.15689)\end{array}$ \\
\hline $\mathrm{GO}_{\mathrm{i}, \mathrm{t}-2}$ & & $\begin{array}{c}0.10828^{\star} \\
(0.05294)\end{array}$ & $\begin{array}{l}0.11982^{\star *} \\
(0.05881)\end{array}$ \\
\hline
\end{tabular}


Continued Table B1.

\begin{tabular}{lccc}
\hline \multicolumn{4}{c}{ Dependent Variable: $\mathrm{I}_{\mathrm{i}, \mathrm{t}}$} \\
\hline $\mathrm{GS}_{\mathrm{i}, \mathrm{t}-2}$ & $\mathrm{I}$ & $\mathrm{II}$ & $\mathrm{III}$ \\
\hline $\mathrm{D}_{08-09}$ & & $0.58919^{\star *}$ & $0.61728^{\star *}$ \\
& & $(0.12939)$ & $(0.15446)$ \\
\hline $\mathrm{CONS}$ & & & $-0.23891^{\star *}$ \\
& & & $(0.06355)$ \\
\hline $\mathrm{R}^{2}$ & $0.02389^{* *}$ & $0.02091^{\star *}$ & $0.02256^{\star *}$ \\
\hline Firms & $(0.00615)$ & $(0.00651)$ & $(0.00725)$ \\
\hline Observations & 0.1877 & 0.2051 & 0.2198 \\
\hline
\end{tabular}

Notes: 1 . CONS is the constant of the regressions; 2 . Standard deviations in parenthesis using cluster option; 3. ${ }^{*}$ statistical significance at $1 \%$ level, ${ }^{*}$ statistical significance at $5 \%$ level; 4 . The estimates include time dummy variables, but are not shown.

\section{APPENDIX C.}

Investment determinants of fitness SMEs - additional determinants

Table C1. Investment determinants of fitness SMEs: more explanatory variables

\begin{tabular}{|c|c|c|c|}
\hline & \multicolumn{3}{|c|}{ Dependent Variable: $I_{i, t}$} \\
\hline & I & II & III \\
\hline SALES $_{\mathrm{i}, \mathrm{t}-1}$ & $\begin{array}{l}0.03152^{\star \star} \\
(0.00812)\end{array}$ & $\begin{array}{l}0.02953^{* *} \\
(0.00704)\end{array}$ & $\begin{array}{l}0.02347^{\star *} \\
(0.00457)\end{array}$ \\
\hline $\mathrm{CF}_{\mathrm{i}, \mathrm{t}-1}$ & $\begin{array}{c}1.2098^{\star *} \\
(0.22691)\end{array}$ & $\begin{array}{l}1.16719^{* *} \\
(0.20752)\end{array}$ & $\begin{array}{l}1.03743^{* *} \\
(0.22450) \\
\end{array}$ \\
\hline $\mathrm{LEV}_{\mathrm{i},-1}$ & $\begin{array}{c}-0.19162^{\star *} \\
(0.07004)\end{array}$ & $\begin{array}{c}-0.13711^{\star *} \\
(0.04019)\end{array}$ & $\begin{array}{c}-0.16224^{* *} \\
(0.04656)\end{array}$ \\
\hline $\mathrm{AGE}_{\mathrm{i},-1}$ & & $\begin{array}{c}0.01813 \\
(0.12087)\end{array}$ & $\begin{array}{c}0.02178 \\
(0.13078)\end{array}$ \\
\hline $\mathrm{GO}_{\mathrm{i}, \mathrm{t}-1}$ & & $\begin{array}{l}0.23445^{\star *} \\
(0.05980)\end{array}$ & $\begin{array}{l}0.19466^{* *} \\
(0.04476)\end{array}$ \\
\hline $\mathrm{GS}_{\mathrm{i}, \mathrm{t}-1}$ & & $\begin{array}{l}0.73489^{* *} \\
(0.16110)\end{array}$ & $\begin{array}{l}0.72889^{* *} \\
(0.18234)\end{array}$ \\
\hline $\mathrm{D}_{08-09}$ & & & $\begin{array}{c}-0.26514^{* *} \\
(0.06889)\end{array}$ \\
\hline ETR $_{\mathrm{i},-1}$ & $\begin{array}{c}-0.15849^{\star *} \\
(0.02819)\end{array}$ & $\begin{array}{c}-0.14293^{\star *} \\
(0.02615)\end{array}$ & $\begin{array}{c}-0.16446^{* *} \\
(0.03019)\end{array}$ \\
\hline $\mathrm{EVOL}_{\mathrm{i}, \mathrm{t}-1}$ & $\begin{array}{c}0.10293 \\
(0.45819) \\
\end{array}$ & $\begin{array}{c}0.12939 \\
(0.54152) \\
\end{array}$ & $\begin{array}{c}0.09717 \\
(0.43828) \\
\end{array}$ \\
\hline CONS & $\begin{array}{l}0.01891^{\star *} \\
(0.00417)\end{array}$ & $\begin{array}{l}0.01283^{\star *} \\
(0.00389)\end{array}$ & $\begin{array}{l}0.01412^{\star *} \\
(0.00415)\end{array}$ \\
\hline $\mathrm{R}^{2}$ & 0.2698 & 0.2987 & 0.3213 \\
\hline Firms & 156 & 156 & 156 \\
\hline Observations & 360 & 360 & 360 \\
\hline
\end{tabular}

Notes: 1 . CONS is the constant of the regressions; 2 . Standard deviations in parenthesis using cluster option; 3. ${ }^{* *}$ statistical significance at $1 \%$ level, ${ }^{*}$ statistical significance at $5 \%$ level; 4 . The estimates include time dummy variables, but are not shown. 
Paulo Maçãs NUNES, PhD in Economics, Associate Professor at the Department of Management and Economics to Beira Interior University and Researcher in CEFAGE-UE (Center for Advanced Studies in Management and Economics). He is the author of articles in various journals: Research Policy, Journal of Evolutionary Economics, etc. The research interests include applied economics, corporate finance, industrial economics and microeconomics.

Zélia SERRASQUEIRO, PhD in Management, Associate Professor at the Department of Management and Economics to Beira Interior University and Researcher in CEFAGE-UE (Center for Advanced Studies in Management and Economics). He is the author of articles in various journals: Research Policy, Journal of Evolutionary Economics, etc. The research interests include corporate finance and entrepreneurial finance.

Pedro GUEDES DE CARVALHO, PhD in Economics, Assistant Professor at theDepartment of Sport Sciences to Beira Interior University and Researcher in CIDESD Research Center, UTAD University. He is the author of various journals such as International Journal of Sport Policy and Politics, etc. The research interests include sport economics, sport management and sport sciences in general. 